\title{
The correlation between serum neuron-specific enolase level in adult patients of oromaxillofacial fracture with mild head injury
}

\author{
M. Ruslin*, H.Y. Yusup ${ }^{* *}$, M.Z. Arifin ${ }^{* * *}$, Noormartany**** \\ *Department of Oral and Maxillofacial Surgery Faculty of Dentistry Universitas Hasanuddin \\ **Department of Oral and Maxillofacial Surgery Faculty of Dentistry Universitas Padjadjaran \\ ***Department of Neurosurgery Faculty of Dentistry Universitas Padjadjaran \\ ****Department of Pathology Faculty of Dentistry Universitas Padjadjaran
}

\section{ABSTRACT}

Oromaxilofacial fracture will have associated with head injury due to its adjacent location and structure. Oromaxillofacial structure is considered to be as force silencer for trauma so that it can protect the intracranial structures. Neuron-specific enolase (NSE) is a specific enzyme within neuron cells and can be detected rapidly in serum. The objective of the study was to investigate the increased serum NSE level in adult patients of oromaxillofacial fracture with mild head injury; and to investigate the correlation between serum NSE level and the location of oromaxillofacial fracture (upper, middle, lower regions, or the combinations) in adult patients of mild head injury. This study used analytical observasional method with cross-sectional design, that conducted in Department of Neurosurgery, Department of Oral and Maxillofacial Surgery, and Laboratory of Clinical Pathology, Dr. Hasan Sadikin Hospital, Bandung, from August to October 2008. The serum NSE level examination was undertaken by blood sample taking then examined with electrochemiluminescence immunoassay (ECLIA). The data were analyzed using MannWhitney test to seek the increased serum NSE level; using Kruskal-Wallis to seek the mean of increased serum NSE levels by location of oromaxillofacial fracture; and using Spearman ranked correlation test to seek the correlation between the increased serum NSE levels and location of oromaxillofacial fracture in adult patients with mild head injury. The study results indicated that there was an increased serum NSE level in adult patients of oromaxillofacial fracture with mild head injury by $13.12 \mathrm{ng} / \mathrm{mL}$ compared to adult healthy group by $7.72 \mathrm{ng} / \mathrm{mL}(\mathrm{p}<0.001)$. By upper, middle, and lower regions of oromaxillofacial fracture, the serum NSE level of oromaxillofacial fracture at combined upper-middle-lower region was significantly the highest, i.e., $21.14 \mathrm{ng} / \mathrm{mL}(\mathrm{p}=0.049)$. A positive correlation between the increased serum NSE level and location of oromaxillofacial fracture caused by mild head injury existed $\left(r_{s}=0.33\right.$, $\mathrm{p}=0.020$ ). In conclusion, there was an increased serum NSE level in adult patients of oromaxillofacial fracture with mild head injury; and there was also a positive correlation between the increased serum NSE level and location of oromaxillofacial fracture due to mild head injury.

Key words: Fracture oromaxillofacial, mild head injury, serum neuron-specific enolase 


\section{INTRODUCTION}

The advancement in industry and technology, particularly in automotive has led to the increasing amounts of vehicles. In line with the increasing vehicle number, the traffic current becomes so heavy that the risk for traffic accident also increases..$^{1-3}$ Approximately $70 \%$ of traffic accidents are with trauma of head, neck and, the most common, oromaxillofacial region. ${ }^{1,4,5}$

Maxillofacial structure is considered to function as a damper of force from severe trauma to neurocranium, ${ }^{5,6}$ whereas some more recent studies suggested that face can significantly spread the traumatic force directly to neurocranium, leading to more severe damage onto the brain. ${ }^{5,7}$

Mechanical biomarker that can be used in head injury is neuron specific enolase (NSE), or Gamma-enolase (ENO-2), is a specific enzyme in neuron cells, it is good to know the neuronal damage and can be detected rapidly in serum and cerebrospinal fluid. ${ }^{8-12}$ The objective of this study was to measure the increase of serum NSE level in adult patients of oromaxillofacial fracture with mild head injury; and to investigate the correlation between the increased serum NSE level and location of oromaxillofacial fracture in patients with mild head injury.

\section{MATERIALS AND METHODS}

During the study period, 88 study subjects were recruited consisting of 48 adult patients of oromaxillofacial fracture with mild head injury as a patient group; these subjects were the patients from Emergency Unit or hospitalized in Department of Neurosurgery or Department of Oral and Maxillofacial Surgery, Dr. Hasan Sadikin Hospital, Bandung. The remaining 40 subjects were healthy people who underwent clinical and laboratory examinations in medical general checkup in Dr. Hasan Sadikin Hospital; and they were as a healthy group of this study.

This study used analytical observasional method with cross-sectional design, that conducted in Department of Neurosurgery, Department of Oral and Maxillofacial Surgery, and Laboratory of Clinical Patholigy, Dr. Hasan Sadikin Hospital, Bandung, from August to October 2008. The serum NSE level examination was undertaken by blood sample taking then examined with electrochemiluminescence immunoassay (ECLIA).

The data were analyzed using Mann-Whitney test to seek the increased serum NSE level; using Kruskal-Wallis test to seek the mean of increased serum NSE levels by location of oromaxillofacial fracture; and using Spearman ranked correlation test to seek the correlation between the increased serum NSE levels and location of oromaxillofacial fracture in adult patients with mild head injury.

\section{RESULTS}

The study results indicated that mean subject age of the oromaxillofacial fracture patients with mild head injury were 27.56 years, with the range of age were 19-65 years; whereas the mean subject age of healthy people were 37.12 years, with the range of age were 19-65 years.

In patient group, there were 48 patients consisting of 41 males and 7 females, with median of 24 years; while in healthy group, there were 40 subjects including 24 males and 16 females) with median of 37 years.

\section{Serum NSE levels in patient group and healthy group}

The mean result of NSE levels in the group of oromaxillofacial fracture patients with mild head injury was $13.12 \mathrm{ng} / \mathrm{ml}$ with SD (standard deviation) of 9.68 and range of 3.19-54.51 ng/ml; it was higher compared to that in healthy group, i.e. $7.72 \mathrm{ng} / \mathrm{ml}$ with SD of 1.82 and range from 4.27 to $10.70 \mathrm{ng} / \mathrm{ml}$. Statistical analysis using Mann-Whitney test indicated that there was an increased serum NSE level in oromaxillofacial fractured patients with mild head injury compared to the healthy group with $p<0.001$ (Tab.1).

Serum NSE level of adult oromaxillofacial farctured patients with mild head injury by gender and fracture location

The mean NSE in female, that is, $17.57 \mathrm{ng} /$ $\mathrm{ml}$ with SD 10.77 was higher than that in male, that is, $11.13 \mathrm{ng} / \mathrm{ml}$ with SD 9.40, indicated that both were statistically non significant using MannWhitney test $(\mathrm{Zmw}=0.174$ and $\mathrm{p}=0.183)$, implying that there was no difference in serum NSE level of adult oromaxillofacial patients with mild head injury by gender ( $p>0.05$ ) (Tab. 2). 
Table 1. Serum NSE level in patient group and healthy group

\begin{tabular}{ccccc}
\hline \multirow{2}{*}{ Group } & \multicolumn{2}{c}{ NSE results $(\mathrm{ng} / \mathrm{mL})$} & \multirow{2}{*}{ Range } & p value \\
\cline { 2 - 3 } & Mean & SD & & \\
\hline Patient group $(\mathrm{n}=48)$ & 13.12 & 9.68 & $3.19-54.51$ & $<0.001$ \\
Healthy group $(\mathrm{n}=40)$ & 7.72 & 1.82 & $4.27-10.70$ & \\
\hline
\end{tabular}

Table 2. Serum NSE levels in adult oromaxillofacial patients with mild head injury by gender and fracture location

\begin{tabular}{|c|c|c|c|c|}
\hline \multirow{2}{*}{ Group } & \multicolumn{2}{|c|}{ NSE results $(\mathrm{ng} / \mathrm{mL})$} & \multirow{2}{*}{ Range } & \multirow{2}{*}{$\mathrm{p}$ value } \\
\hline & Mean & SD & & \\
\hline By gender & & & $Z_{M W}=0.174$ & $0.183^{*}$ \\
\hline Male & 11.13 & 9.40 & & \\
\hline Female & 17.57 & 10.77 & & \\
\hline By fracture location & & & $\mathrm{X}_{\mathrm{KW}}^{2}=9.518$ & $0.049^{* *}$ \\
\hline Upper & 12.42 & 7.68 & & \\
\hline Upper-middle & - & - & & \\
\hline Upper-lower & - & - & & \\
\hline Upper-middle-lower & 21.14 & 10.51 & & \\
\hline Middle & 7.88 & 2.64 & & \\
\hline Middle-lower & 11.97 & 5.63 & & \\
\hline Lower & 15.44 & 15.34 & & \\
\hline
\end{tabular}

Note: ${ }^{*} \mathrm{Z}_{\mathrm{MW}}=$ Mann-Whitney test, ${ }^{*} \mathrm{X}_{\mathrm{KW}}{ }=$ Kruskall-Wallis test.

Table 3. The Correlation between serum NSE level of adult oromaxillofacial patient with mild head injury and the location of fracture

\begin{tabular}{lcc}
\hline \multicolumn{1}{c}{ Correlation with NSE } & ${ }^{*} \mathrm{r}_{\mathrm{s}}$ & $\mathrm{p}$ value \\
\hline Location & & \\
$\quad$ Upper & 0.25 & 0.091 \\
Upper-middle & - & - \\
Upper-lower & - & - \\
Upper-middle-lower & 0.37 & 0.020 \\
Middle & 0.05 & 0.726 \\
Middle-lower & 0.02 & 0.897 \\
Lower & 0.23 & 0.121 \\
\hline Total & 0.33 & 0.020 \\
\hline Note: ${ }^{*}$ r Spearman ranked correlation coefficient.
\end{tabular}

The highest mean of NSE level in oromaxillofacial fracture in location of uppermiddle-lower third facial parts was $21.14 \mathrm{ng} / \mathrm{ml}$ with SD 10.51; the mean lower third facial part $(15.44 \mathrm{ng} / \mathrm{ml}$ with SD of 15.34$)$ was higher than that of upper third facial part $(12.42 \mathrm{ng} / \mathrm{ml}$ with SD 7.68); and the mean NSE level in middle-lower facial third parts, that is $11.97 \mathrm{ng} / \mathrm{ml}$ with SD 5.63 , was higher that in middle facial part, that is 7.88 with SD 2.64. There was no criteria of uppermiddle and upper-lower facial parts. The statistical analysis using Kruskall-Wallis yielded $\mathrm{X}_{\mathrm{KW}}^{2}=9.518$ and $p=0.049$ implying significant, meaning that there was a difference in serum NSE level of adult oromaxillofacial fracture patients with mild head injury by location of fracture $(p \leq 0.05)$ (Tab. 2$)$.

The correlation of serum NSE level of adult oromaxillofacial fracture patient with mild head injury to the location of fracture

The results of statistical analysis using Spearman ranked correlation test showed that one affected facial part did not correlate significantly each other in upper, middle, and lower facial part with $p=0.091, p=0.726$. and $p=0.121$, respectively. Similarly, the involvement of two facial parts did not correlate significantly with $\mathrm{p}=0.897$; however, in three location they correlated significantly with $r s=0.33, p=0.020$ indicating that there was a positive correlation between the increased serum NSE level of adult oromaxillofacial patient with mild head injury and the location of fracture $(p \leq 0.05)($ Tab. 3).

\section{DISCUSSION}

The mean age in this study was 24 years, 
this result showed high incidence rate of oromaxillofacial trauma with mild head injury in line with the increasing social economic activity of people, proved with the fact that most of the productive age people are more dominant in community as well as more active and mobile in this age, as suggested in the study of Laski et al. ${ }^{1}$ The study results indicated that most patients were oromaxillofacial fracture adult with mild injury with ratio of male to female was 5.8:1. This conforms to the results of several previous studies suggesting that maxillofacial trauma with head injury was more in male compared to that in female. The reason is that males are more active and more mobile as well as generally more responsible to earn living for their families.

\section{Serum NSE levels in adult patient and in healthy people}

Tabel 2 shows that the mean of serum NSE level in patient group was 1.7 times greater than that in healthy group $(p \leq 0.05)$. Theoritically, in general, oromaxillofacial fractures will be not independent on head injury, in the reason that the structure and location are adjacent each other. The patients of oromaxillofacial fracture are frequently with head injury such as intracranial haemorrhage, fractured cranial base, and unconsciousness, leading to the damage of central nerve system..$^{5,13,14}$

According to the study of Davidoff et al. ${ }^{15}, 55 \%$ bony facial fracture had concomitant head injury, and in parallel with Haug's study. ${ }^{16}$ reporting $17.5 \%$ of head injury incidence in bony facial fracture. This can explain that at the time of neuronal damage and the cellular membrane disturbance, the activation of protease enzyme occurred producing neuroprotein product (NSE) that may penetrate across blood-brain barrier then diffuse into blood vessels an cerebrospinal fluid so that the detection of neuronal damage can be undertaken through blood and cerebrospinal NSE levels ${ }^{8,9,17}$, in line with several studies suggesting that NSE level examination in serum and cerebrospinal fluid are helpful in measurement the brain injury; ${ }^{9,12,18,19}$ this enables NSE rapidly detectable after head injury.

Thus, it can be said that at the time oromaxillofacial fracture occurs with mild head injury, neuronal damage detection can be done by the measurement of blood NSE level, thereby NSE level measurement can be used as one of markers for head injury.

Serum NSE levels in adult oromaxillofacial patients with mild head injury by gender and fracture location

Table 3 indicates that there was no difference in serum NSE levels of adult oromaxillofacial fracture patients with mild head injury by gender $(p=0.183)$. In the study conducted by Hayes and Wu et al. ${ }^{12}$, this supporting result suggested that serum NSE level did not correlate to the gender.

Based on analysis with Kruskal-Wallis test, NSE level of adult oromaxillofacial patients with mild head injury by the location of the fractures indicated the significant difference $(p=0.049)$ (Tab.3). The lowest NSE level was at oromaxillofacial trauma of middle third facial part, implying the mechanism of oromaxillofacial stucture was as the damper for traumatic force in order to protect neurocranium from heavy trauma. ${ }^{5,6}$ So that, in principle, that oromaxillofacial anatomy has vertical supporting walls, i.e., nasomaxillar, zigomaticomaxillar, and pterigomaxillar buttresses; and the very recent study added that there was horizontal support, i.e., lateral anthrum, medial nasal wall, and zygomatic arc. ${ }^{7,20}$ This study results conforms to the view of Lee et al. ${ }^{6}$ but different from Keenan et al. study. ${ }^{21}$

The results of serum NSE level at upper oromaxillofacial third part was higher than that at middle one as seen at Table 3. This indicates that there was no force damper against trauma onto frontal bone; thus at the time of traumatic occurrence, the force can spread directly into neurocranium leading to more severe injury of brain, in accordance to the study of Lee et al. ${ }^{6}$ that the risk for head injury with maxillofacial trauma tend to be higher at upper third facial part.

Heavy contact trauma can also cause skull fracture. The skull fracture may cause then arterial or venous injury, leading to haemorrhage into brain tissue. In depressed skull fracture, brain damage occurs more severe. Bacteria may get into the brain through the crack, causing infection and severe brain damage. ${ }^{22,23}$

The study results at lower oromaxillofacial third part indicated that mandular fracture had 
greater risk for head injury, different from Lee et al. study ${ }^{6}$ suggesting that mandibular fracture had lesser risk for head injury. Theoritically, it can be explained that head injury are of two mechanism, contact mechanism or direct impact and acceleration-deceleration mechanism. ${ }^{23-25}$ In acceleration-deceleration mechanism, the impact on head rises rapid, sudden movement. At the time of acceleration occurs, there are two events, that is, rapid skull movement in the same direction of impact force movement and the shifting of brain toward opposite to impact direction. At the deceleration, once again, the brain shifts toward the original position. Both events cause the brain swings reciprocally. ${ }^{23,25,26}$ This explains why some patients with lower oromaxillofacial third part without other facial fractures has more severe head injury.

In Table 3, NSE level was higher at the location of fracture involving three area, that is, upper-middle-lower part. It indicates that the more oromaxillofacial part involved, the more the neuronal injury occur. The samples of uppermiddle and upper-lower oromaxillofacial third parts were not found during this study period.

The correlation of serum NSE levels of adult oromaxillofacial patients with mild head injury to fracture location

Statistical analysis using Spearman ranked correlation test indicated that there was appositive correlation between serum NSE level of adult patient and the location of oromaxillofacial fracture with mild head injury $(p=0.020)$. It can explain that if there is an oromaxillofacial fracture, it will result in neuronal damage that is characterized by the activation of protease enzyme leading to produce NSE which is able to cross blood-brain barrier, then diffuses into blood vessels and cerebrospinal fluid.

\section{CONCLUSION}

There is an increased serum NSE level of adult oromaxillofacial fracture patients with mild head injury and a positive correlation between the increased serum NSE level of adult patients and the location of oromaxillofacial fracture with head injury.

\section{REFERENCES}

1. Laski R, Ziccardi VB, Broder HL, Janal Malvin. Facial trauma: a recurrent disease? The potential role of disease prevention. J Oral Maxillofac Surg 2004;62:685-8.

2. Ansari MH. Maxillofacial fractures in Hamedan province, Iran: A retrospective study (19872001). J Cranio Maxillofac Surg 2004;32:2834.

3. Olasoji HO, Tahir A, Arotiba GT. Changing picture of facial fractures in Northern Nigeria. Br J Oral Maxillofac Surg 2002;40:140-3.

4. Adebayo ET, Ajike OS, Adekeye EO. Analysis of the pattern of maxillofacial fractures in Kanduna, Nigeria. Br J Oral Maxillofac Surg 2003;41:396-400.

5. Ruslin M, Arifin MZ. The Correlation between maxillofacial fracture with intracranial haematoma, skull base fracture and decrease of consciousness at head injury. Bandung Med J 2007;39(3):115-9.

6. Lee KF, Wagner LK, Lee YE. The impactabsorbing effect of facial fractures in closedhead injuries. J Neurosurg 1987;66:542.

7. Plaisier BR, Punjabi AP, Super DM, Haug RH. The relationship between facial fractures and death from neurologic injury. J Oral Maxillofac Surg 2000;58:708-12.

8. Pineda JA, Wang KKW, Hayes R. Biomarkers of proteolytic damage following traumatic brain injury. Brain Pathol 2004;14:202-9.

9. Wang KKW, Ottens AK, Liu MC, Lewis SB, Meegan $C$, Oli $M W$, et al. Proteomic identification of biomarkers of traumatic brain injury. Proteomics 2005;2(4):1-12.

10. Hayes RL. Biochemical markers of brain injury: applications to combat casualty care. Presented at the RTO HFM Symposium on combat casualty care in ground based tactical situations: Trauma technology and emergency medical procedures. USA, 16-18 August 2004.

11. Laterza OF, Modur VR, Crimmins DL, Olander JV, Landt Y, Lee JM, et al. Identification of novel brain biomarkers. Clin Chemistry 2006;52(9):1713-21.

12. Wu YC, Zhao YB, Lu CZ, Qiao J, Tan YJ. Correlation between serum level of neuronspecific enolase and long-term functional 
outcome after acute cerebral infarction: prospective study. Hong Kong Med J 2004;10:251-4.

13. Malara P, Malara B, Drugacz J. Characteristics of maxillofacial injuries resulting from road traffic accidents - A 5 year review of the case records from Department of Maxillofacial Surgery in Katowice, Poland. Head \& Face Med 2006;2:7.

14. Kloss FR, Tuli T, Hachl O, Laimer K, Jank S, Stempfl K, et al. The impact of ageing on cranio-maxillofacial trauma - A comparative investigation. Int J Oral Maxillofac Surg 2007;36:1158-63.

15. Davidoff G, Jakubowski M, Thomas D. The spectrum of closed-head injuries in facial trauma victims: Incidence and impact. Ann Emerg Med 1988;17:6-9.

16. Haug R, Savage J, Likavec M. A review of 100 closed head injuries associated with facial bone fractures. J Oral Maxillofac Surg 1992;50:218-22.

17. Pelinka LE. Serum marker of severe traumatic brain injury: Are they useful?. Presented at the $17^{\text {th }}$ Annual Trauma Anesthesia and Critical Care Symposium, Sydney, Australia. 2004 Oct 15-17.

18. Roine RO, Somer $H$, Kaste M, Viinikka L, Karonen SL. Neurological outcome after out-of-hospital cardiac arrest: Prediction by cerebrospinal fluid enzyme analysis. Arch Neurol 1989;46:753-6.

19. Fogel W, Krieger D, Veith M, Adams HP,
Hund E, Storch-Hagenlocher B, et al. Serum neuron-specific enolase as early predictor of outcome after cardiac arrest. Crit Care Med 1997;25:1133-8.

20. Haskell R. Applied surgical anatomy. In: Williams JLI, Murley SR (editors). Rowe and Williams' maxillofacial injuries. Vol. 1. $2^{\text {nd }}$ ed. London: Churchill Livingstone; 1994. p. 1930.

21. Keenan H, Brundage S, Thompson D. Does tha face protect the brain? Arch Surg 1999;134:147.

22. Butterfield KJ, Piecuch JF, Fletcher MC, Bucci $M N$. Neurologic evaluation and management. In: Fonseca RJ, Walker RV, Betts NJ, Barber HD, Powers MP (editors). Oral and maxillofacial surgery. Vol. 1. $3^{\text {rd }}$ ed. St. Louis: Elsevier Saunders; 2005. p. 209-26.

23. Seelig JM, Marshall LF. Biomechanic of head injury: clinical aspects. In: Nahum AM, Melvin J. The biomechanic of trauma. Connecticut: Appleton Century Crofts; 1985. p. 271-80.

24. Dombovy ML. Traumatic brain injury. In: Lazar RB. Principles of neurologic rehabilitation. USA: McGraw-Hill; 1998. p. 79-90.

25. Ommaya AK. Biomechanic of head injury: experimental aspects. In: Nahum AM. The biomechanic of trauma. Connecticut: Appleton Century Crofts; 1985 . p. 245-70.

26. Blumbergs PC. Pathology. In: Reilly P, Bullock $\mathrm{R}$ (editors). Head injury pathophysiology and management of severe closed injury. London: Chapman \& Hall Medical; 1997. p. 39-61. 